\title{
Actividad antioxidante de los extractos de Chiltepin (Capsicum annum) cultivados bajo redes de colores.
}

\author{
Antioxidant activity of the extracts of Chiltepin (Capsicum annum) cultivated under colored \\ shade nets
}

\author{
Reyes-Acosta D.J ${ }^{a}$, Álvarez- Parrilla $E^{a}$, Jiménez-Alvarado $R^{a}$, Campos-Montiel R.G ${ }^{a}$ \\ Hernández- Fuentes A.D ${ }^{a}$
}

\begin{abstract}
:
Chiltepín or piquin chili pepper (Capsicum annum) is a wild resource of wide geographic distribution in the Mexican Republic. The aim of this study was to evaluate the effect of different types shadow black, red, white blue and plastic cover mesh base on the content of total phenols and antioxidant capacity in chiltepin fruits. They were analyzed in chiltepin fruit extracts in total phenol conten (FolinCiocalteu) antioxidant capacity (ABTS and DPPH) by spectrophotometric techniques and were quantified and identified phenols and capsaicinoids. The results indicated that shade and plastic cover meshes do influence the content of phenols and capsaicinoids. The content of phenols and capdsaicinoids in chiltepín fruits indicate the potenctial in obtaining bioactive compounds with antioxidant and antibacterial capacity
\end{abstract}

\section{Keywords:}

Chiltepin pepper, phytochemical, capsaicinoids, colored shade nets, plastic cover

\section{Resumen:}

El chile chiltepín o piquín (Capsicum annuum) es un recurso silvestre de amplia distribución geográfica en la República Mexicana. El objetivo del trabajo fue evaluar el efecto de malla sombra negra, roja, blanca, azul y cubierta de plástico con base en el contenido de fenoles totales y capacidad antioxidante en frutos de chiltepín. Se analizaron en los extractos de frutos de chiltepin en contenido de fenoles totales (Folin Ciocalteu), capacidad antioxidante (ABTS y DPPH) por técnicas espectrofotométricas y se cuantificaron e identificaron fenoles y capsaicinoides por HPLC-DAD. Los resultados indican que las mallas sombra y cubierta plastica si influyen en el contenido de fenoles y capsaicinoides. El contenido de fenoles y capsaicinoides en frutos de chiltepín indican el posible potencial en la obtención de compuestos bioactivos con capacidad antioxidante y antibacteriana.

\section{Palabras Clave:}

Chile chiltepín, Fitoquímicos, Capsaicinoides, Mallas de colores, cubiertas de plástico

\section{Introduction}

The chiltepin or piquin pepper (Capsicum annuum) is a wild plant resource of wide geographical distribution in the Mexican Republic. For the people of the northeastern region of Mexico, this species represents a food and medicinal source (Márquez Quiroz, 2013). The fruit of piquín chili has historically been consumed in the communities surrounding the production áreas without risking their survival (Sandoval Rangel A. , 2011).

a Autor de Correspondencia, Universidad Autónoma del Estado de Hidalgo, Instituto de Ciencias Agropecuarias, Email: deliareyesacosta@gmail.com, ealvarez@uacj.mx,ruben_jimenez@uaeh.edu.mx,rcampos@uaeh.edu.mx, hfad@hotmail.com. 
The use of shade nets is a strategy to protect plants from direct solar radiation, reduce the number of fruits with damage also to obtaining more vigorous plants better pest control and greater profitability of crops than in the open field (Shahak, 2008) (Ayala Tafoya, 2015).Many pepper species have not been analyzed for their concentrations of ascorbic acid, capsaicin, and total phenolic compounds, which are important antioxidants having a number of benefits for the human health (Antonious, 2006).

However, the composition of the fruit's changes depending on the maturation stage and the environmental conditions in which the fruits were produced and in the case of the cultivated varieties (Vera Guzmán, 2011).

For all it is necessary to know the effect of the agronomic management in shaded nets production technology on the quality in chili peppers.

\section{Materials and methods}

\section{Collection of fruits}

Fresh fruits of selected chiltepín (C. annuum) from Saltillo Coahuila, México of the ecotype Rio tuxpan Zacatecas. The fruits of chiltepín were washed and frozen at $-80^{\circ} \mathrm{C}$ for 1 day, freeze dried for $48 \mathrm{~h}$, milled in a laboratory miller and stored at $-80^{\circ} \mathrm{C}$.

\section{Total phenolics content}

Total phenolic content in chiltepín chili's fruit was determineed with Folin-Ciocalteu reagent according to the method of Waterman et al, 1994, using galic acid as a standard phenolic compound. $150 \mathrm{mg}$ of biomass dried were placed in a tuve, with $20 \mathrm{~mL}$ de methanol $(100 \%)$, grinded at $5^{\circ} \mathrm{C}$ and centrifuged at $14000 \times \mathrm{g}$ for $10 \mathrm{~min}$. Reaction mixture consisted of mixing $0.5 \mathrm{~mL}$ of the extract added with $1.5 \mathrm{~mL}$ of $\mathrm{Na}_{2} \mathrm{CO}_{3}$ and $0.5 \mathrm{~mL}$ of Folin-Ciocalteu.

\section{Total antioxidant activity}

Antioxidant capacity of chiltepín samples was determined by different assays described below.

\section{DPPH}

The DPPH assay was performed according to the method described by Brand-Williams et al; 1995.

\section{ABTS}

The ABTS assay was performed accordind to te method described by Re, R; et al 1999.

\section{Identification and quantification of phenolic compounds by HPLC- DAD}

Identification and quantification of phenolic compounds in samples of pepper were carried out following the method described by de la

Rosa, Alvarez-Parrilla, and Shahidi (2011) with slight modifications. Before HPLC analysis, samples were hydrolyzed, by mixing $30 \mathrm{mg}$ of each simple with $10 \mathrm{~mL}$ of acidified methanol and heating to 95 ${ }^{\circ} \mathrm{C}$ for $60 \mathrm{~min}$. Samples were cooled and extracted with $10 \mathrm{~mL}$ of ethyl ether in triplicate. The organic phasewas recovered, solvent evaporated and dry solids suspended in methanol ( $1 \mathrm{mg} / \mathrm{mL}) .15 \mu \mathrm{L}$ of 
this solution was filtered through a $0.45 \mu \mathrm{m}$ filter and injected into a Perkin Elmer model 200 series HPLC equipment with diode array detector (DAD).

Separation was achieved using a SupercosilL C18 column $(250 \times 4.6 \mathrm{~mm}, 5 \mu$, Phenomenex Inc., Torrence CA), a binary mobile phase was used (solvent $A$, acetonitrile $5 \%$ in methanol; solvent $B$, formic acid $1 \%$ in water) with the following gradient program. A flux rate of $1 \mathrm{~mL} / \mathrm{min}$ was used and detection wavelengths were 280 and $320 \mathrm{~nm}$. Identification and quantification of phenolic compounds was achieved by comparison of retention time (rt) and

UV spectrawith those of pure standards (gallic acid, catechin, quercetin, chlorogenic acid, caffeic acid)

\section{Identification and quantification of capsaicinoids by HPLC-DAD}

Capsaicinoids in chiltepín peppers were identified and quantified according to the method describe by Alvarez-Parrilla et al. (2011). Briefly, $0.5 \mathrm{~g}$ of freeze-dried samples was extracted with $10 \mathrm{~mL}$ of methanol by sonication in the dark for $20 \mathrm{~min}$. Then samples were centrifuged at $2000 \mathrm{~g}$ for $5 \mathrm{~min}$ and supernatant was collected.

The extraction was repeated, and both supernatants were combined and stored at $-20{ }^{\circ} \mathrm{C}$ until analysis. Identification and quantification of capsaicinoids were carried out in the HPLC equipment formerly described with a Supercosill C-18 reverse-phase column ( $5 \mu \mathrm{m}$ particle size, $250 \times 4.60 \mathrm{~mm}$ i.d., Phenomenex, Torreance, CA, USA). A $25 \mu \mathrm{L}$ aliquot of filtered ( $0.45 \mu \mathrm{m}$ nylon syringe filter) extract was injected into the system and eluted using an isocratic mobile phase at a $1 \mathrm{~mL} / \mathrm{min}$ flow rate.

Capsaicinoids were detected at $280 \mathrm{~nm}$; capsaicin (CAP; rt $23 \mathrm{~min}$ ) and dihydrocapsaicin (DHC; rt 34 $\min$ ) were quantified using pure

standard compounds, and results expressed as $\mu \mathrm{g}$ CAP or DHC/g DW.

\section{Statistical analysis}

All analyses were carried out by triplicate. Values were expressed as mean \pm standard deviation (SD). One-way analysis of variance

(ANOVA), and Tukey analyses were performed in order to determine statistical differences $(p<0.05)$ between the samples.

\section{Results and discussion}

\section{Concentrations of total phenols}

Total phenolic content (table1) of dry chiltepín samples grown in greenhouse had the highest concentration, then open field and with concentrations below the previous ones were the different black, red, white and blue shades.

The production of these compounds in chiltepin fruits could be due to the conditions thar are stress for the plant. The found values allow to confirm that if the content of these bioactive compounds influences under the different types of shade mesh and plastic cover. 
Table 1. Total phenolics content of chiltepín peppers.

\begin{tabular}{ll}
\hline Type shade nets & $\begin{array}{l}\text { Total Phenols } \\
\text { (mg EGA/g PS) }\end{array}$ \\
\hline Open field & $39.24 \pm 0.59^{\mathrm{b}}$ \\
Greenhouse & $54.45 \pm 1.38^{\mathrm{a}}$ \\
Black mesh & $36.90 \pm 0.03^{\mathrm{c}}$ \\
Red mesh & $36.07 \pm 0.42^{\mathrm{cd}}$ \\
White mesh & $34.44 \pm 0.03^{\mathrm{d}}$ \\
Blue mesh & $34.85 \pm 0.28^{\mathrm{d}}$ \\
\hline
\end{tabular}

Values represent the mean of three or four measurements. Values in the same column with different letters are significaly different (Tukey test, $P<0.05$ ).

The antioxidant capacity obtained from the different types of shade mesh and plastic cover where chiltepin is grown shows significant differences between them as can be seen in table 2 . In this table you can see note that the extract that showed the highest antioxidant activity for the ABTS radical was chiltepin cultivated in a greenhouse (plastic cover), while for the DPPH radical was the extract of chiltepin cultivated in open field (without shade mesh).

Table 2. Total phenolics content of chiltepín peppers.

\begin{tabular}{llc}
\hline Type shade nets & $\begin{array}{l}\text { ABTS } \\
(\mu \mathrm{M} \text { Trolox/g PS })\end{array}$ & $\begin{array}{c}\text { DPPH } \\
(\mu \mathrm{M} \text { Trolox/g PS })\end{array}$ \\
\hline Open field & $85.26 \pm 0.45^{\mathrm{b}}$ & $28.73 \pm 0.05^{\mathrm{a}}$ \\
Greenhouse & $93.45 \pm 0.72^{\mathrm{a}}$ & $26.21 \pm 0.03^{\mathrm{b}}$ \\
Black mesh & $83.95 \pm 0.18^{\mathrm{b}}$ & $21.06 \pm 0.09^{\mathrm{c}}$ \\
Red mesh & $77.37 \pm 0.17^{\mathrm{c}}$ & $18.87 \pm 0.50^{\mathrm{d}}$ \\
White mesh & $82.45 \pm 3.50^{\mathrm{b}}$ & $17.81 \pm 0.48^{\mathrm{d}}$ \\
Blue mesh & $67.14 \pm 2.24^{\mathrm{d}}$ & $18.53 \pm 0.87^{\mathrm{d}}$ \\
\hline
\end{tabular}

Values represent the mean of three or four measurements. Values in the same column with different letters are significaly different (Tukey test, $P<0.05$ ). 


\section{Identification and quantification of phenolic compounds by HPLC- DAD}

The fruits of chiltepin cultivated under open field (figure 1) had a higher content of galic acid and catechin, however the fruits cultivated under black mesh have a higher concentration of chlorogenic acid.

\section{Identification and quantification of capsaicinoids by HPLC-DAD}

The most abundant compound in all the samples was capsaicin with a range of 68 to $78 \%$ of the total of the capsaicinoids of all the samples. The chiltepin sample cultivated in the greenhouse (figura 2) was the highest concentration with capsaicin values of $10.97 \mathrm{mg} / \mathrm{g}$ and $3.07 \mathrm{mg} / \mathrm{g}$ od dihydrocapsaicin.

\section{Conclusion}

The use of color meshes and plastic tray that were used in this study caused changes in the physicochemical quality, however, the values of the parameters are within good quality fruits. On the other hand, the amount of phytochemicals and antioxidant capacity were affected a little by greater amount of shade presenting low concentrations. Therefore, the results of the present work showed that the conditions provided by the meshes present an impact on the levels of phytochemicals and antioxidant capacity.

\section{Literature cited}

Alvarez Parrilla, E. D. (2011). Antioxidant Activity of Fresh and Processed Jalapeño and Serrano Peppers. Journal of Agricultural and Food Chemistry., 59, 163-173.

Antonious, G. F. (2006). Antioxidants in Hot Pepper: Variation among accessions. Journal of Environmental Science and Health Part B., 41, 1237-1243.

Ayala Tafoya, F. M. (2015). Producción de pimiento morrón con mallas sombras de colores. Rev. Fitotec. Mex., 1, 93-99.

Márquez Quiroz, C. L. (2013). Fertilización orgánica: Una alternativa para la producción de chile piquín bajo condiciones protegidas. Revista Chapingo Serie Horticultura., 19(3), 279-286.

Sandoval Rangel, A. (febrero de 2011). El cultivo del chile piquín y la influencia de los ácidos orgánicos en el crecimiento, productividad y calidad nutricional. Tesis Doctorado en Ciencias. San Nicolas de los Garza, Nuevo Leon, Mexico.

Shahak, Y. G. (2008). Photoselective shade netting integrated with greenhouse technologies for improved performance of vegetable and arnamental crops. Acta Hort., 75-80.

Vera Guzmán, A. M. (2011). Phytochemical evaluation of wild and cultivated pepper (Capsicum annuum L. and C. pubescens Ruiz \& Pav.) From Oaxaca, Mexico. Chilean Journal of Agricultural Research, 71(4), 578. 